DOI: $10.1515 /$ pts-2017-0038

\title{
A METHODOLOGY FOR THE ESTIMATION OF THE WIND GENERATOR ECONOMIC EFFICIENCY
}

\author{
G. Zaleskis \\ Riga Technical University, Faculty of Power and Electrical Engineering, Institute \\ of Industrial Electronics and Electrical Engineering, \\ 12-1 Azenes Str., Riga, LV-1048, LATVIA \\ e-mail: genadijs.zaleskis@rtu.lv
}

\begin{abstract}
Integration of renewable energy sources and the improvement of the technological base may not only reduce the consumption of fossil fuel and environmental load, but also ensure the power supply in regions with difficult fuel delivery or power failures. The main goal of the research is to develop the methodology of evaluation of the wind turbine economic efficiency. The research has demonstrated that the electricity produced from renewable sources may be much more expensive than the electricity purchased from the conventional grid.
\end{abstract}

Keywords: energy resources, renewable energy sources, wind energy.

\section{INTRODUCTION}

Prerequisites of the use of the wind turbine are the following:

- $\quad$ strategic objectives of the use of the renewable energy sources [1]-[3];

- $\quad$ political aspects [4]-[6].

One of the most important economic benefits of wind power is the reduction of economic dependence on fossil fuel. This benefit is substantial enough to justify the expansion of wind energy in several European countries, even if wind energy price per $\mathrm{kWh}$ is higher than for other forms of energy production, although this risk reduction is not currently included in the standard methods for the calculation of the energy price [7]. Wind energy price depends on several factors [7]-[9], but, in general, these may be defined as follows: installation and operation costs, operation period and capacity factor.

According to the electricity NET payment system [10] for the microgenerators [11], energy produced by wind turbines can be sold to the conventional power grid operator in accordance with the market price [6], which is variable.

The method for the wind turbine efficiency evaluation was presented in [13]. The aim of present research is to improve the method by specification of used parameters and introduction of new variables. Detailed methodology shall help estimate 
the economic efficiency of wind generators in specific conditions.

The market price of electricity is applied equal to 0.065 EUR per $\mathrm{kWh}$, according to [13]. It is also assumed that the necessary energy can be purchased from the grid operator; in this case the price is 0.16 EUR per $\mathrm{kWh}$. For the general assessment of the economic efficiency of wind turbines, the special rules of the grid operator are not taken into account.

According to [14], it was decided [3] that the DC microgrids were necessary for integration of renewable sources. Therefore, the proposed methodology is based on the power relations in the DC microgrid with a wind generator as the main energy source [13].

\section{THE MAIN PARAMETERS DESCRIBING POWER FLOWS IN THE WIND ENERGY BASED MICROGRID}

The power flows in the alternative energetics microgrid are explained using an example of the DC microgrid, since such configuration is more suitable for the integration of the renewables [15] - [17]. The presented microgrid (Fig. 1) includes the wind turbine producing annually averaged power $P_{w, a v}$ which is partially consumed by load with annually averaged power $P_{\text {load,av }}$ [13]. The difference of the both powers should be transmitted through the bidirectional converter to the conventional AC grid:

$$
P_{\text {grid }, a v}=P_{w, a v}-P_{l o a d, a v},
$$

where $P_{\text {grid,av }}$ - averaged power transmitted to the grid, W;

$P_{w, a v}$ - averaged power produced by the turbine, $\mathrm{W}$;

$P_{\text {load, av }}$ - averaged power consumed by load, W.

Wind turbine producing average power is characterised with the capacity factor $\alpha$, which is the ratio indicator of wind power utilisation during a year:

$$
\alpha=\frac{P_{w, a v}}{P_{w, r}}<1 .
$$

Part of the averaged wind power is consumed by the microgrid load, and its averaged consumed wind power can be characterised with the wind turbine power distribution factor:

$$
\beta=\frac{P_{\text {load }, a v}}{P_{w, a v}}=\frac{P_{\text {load }, a v}}{\alpha \cdot P_{w, r}} .
$$

The wind turbine power distribution parameter can be smaller than 1 (and surplus wind energy should be transmitted to the grid) as well as above 1 (when energy flow of the grid supports the needs of consumers). 
Using (1), (2) and (3) the power transferred through the conventional grid is:

$$
P_{\text {grid }, a v}=\alpha \cdot P_{w, r}-\beta \cdot P_{w, a v}=\alpha \cdot(1-\beta) \cdot P_{w, r}
$$

The specific averaged power of the AC grid is the ratio between the averaged AC grid power $P_{\text {grid,av }}$ and the rated power of the wind turbine:

$$
P_{g r i d, u}^{*}=\frac{P_{g r i d, u}}{P_{w, r}}=\alpha \cdot(1-\beta)=\alpha-(\alpha \cdot \beta),
$$

where $(\alpha \cdot \beta)$ is the specific averaged load power.

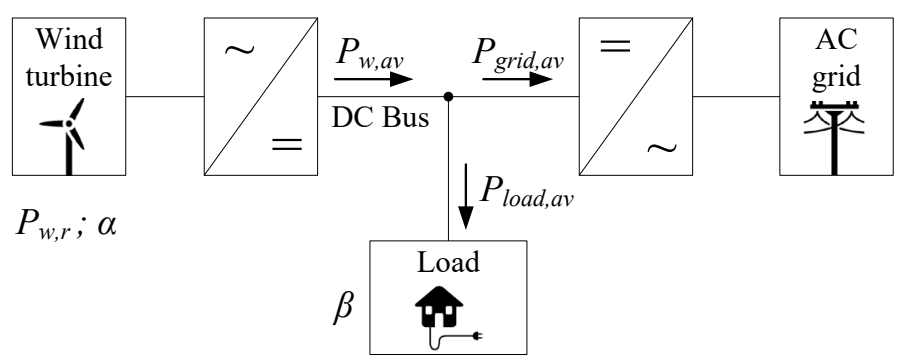

Fig. 1. Power relations in the wind energy based DC microgrid: $P_{w, r}-$ the rated power of the wind turbine; $\alpha$ - the capacity factor; $P_{w, a v}$ - the average power of the wind turbine; $P_{g r i d, a v}$ - the average power of the AC power grid; $P_{\text {load, }, v}$ - the average power of the load; $\beta$ - the wind power utilisation factor.

According to Fig. 1 and (5), the sign of the AC grid average power $P_{\text {grid,av }}$ depends on load power needs and wind turbine generated power. The sign "+" means that surplus of wind energy is transferred to the AC grid; the sign "-" means that load needs of power are in full or in part covered by the AC grid energy.

\section{FACTORS INFLUENCING THE PRICE OF THE ENERGY PRODUCED BY WIND GENERATOR}

Accepting an approach that annual price of electrical energy produced by the wind turbine can be presented as reduced to the year, as opposed to [18], total annual expenses of wind power [13], [19] plant can be presented as follows:

$$
C_{w}=k_{a} \cdot C_{k W} \cdot P_{w, r}
$$

where $C_{k W}$ - installation expenses of $1 \mathrm{~kW}$ installed power of plant, including power converter costs;

$k_{a}$ - reduction factor for cost of installed power. 
Reduction factor $k_{a}$ [13] characterises possible time duration in years of normal operation $T_{o p}$ of the constructed plant as well the relative part $k_{\text {exp }}$ of annual operation costs:

$$
k_{a}=\frac{1}{T_{o p}} \cdot k_{o p} .
$$

The actual price of $1 \mathrm{kWh}$ of the produced electrical energy can be calculated as follows:

$$
C_{k W h}=\frac{C_{k W} \cdot k_{a}}{T_{a n} \cdot \alpha},
$$

where $T_{a n}=8760$ is a number of hours in a year.

Thus, the price of the produced wind energy significantly depends on the installation investments and the ratio indicator of wind power utilisation (Fig. 2).

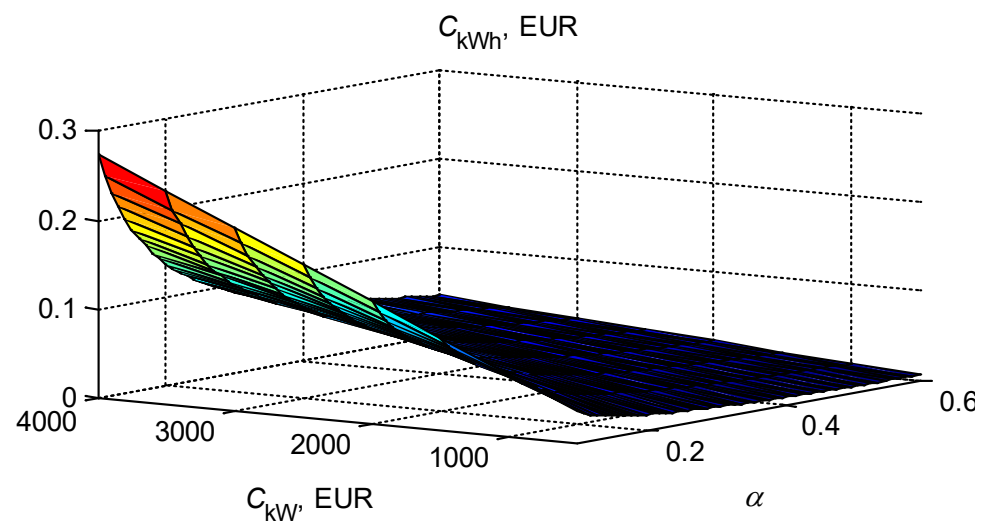

Fig. 2. The price of the energy produced by the wind generator depending on installation investments and capacity factor.

\section{COVER OF EXPENDITURE AND REVENUE OPPORTUNITIES}

If the AC grid average power $P_{g r i d, a v}$ is positive, the income from electrical energy sales to the conventional grid is observed. In terms of money, this income is equal to:

$$
C_{\text {grid }}=P_{\text {grid }, a v} \cdot T_{a n} \cdot C_{k W h, \text { market }},
$$

where $C_{k W h \text {,market }}$ - the market price for the electrical energy, EUR $/ \mathrm{kWh}$. 
If the AC grid average power $P_{g r i d, a v}$ is negative, the amount of the bought energy in terms of money is equal to:

$$
C_{\text {grid }}=P_{\text {grid }, a v} \cdot T_{a n} \cdot C_{k W h, g r i d},
$$

where $C_{k W h \text { grid }}$ - the AC grid operator price for the electrical energy, EUR/kWh.

The AC grid operator price $C_{k W h \text {,grid }}$ is higher than the market price because the operator price includes payments for the distribution operator service and the mandatory procurement component. Thus, common economic efficiency of the wind turbine is calculated using the economic efficiency factor of annual energy production $C_{w, \text { com }}$ :

$$
C_{w, \text { com }}=C_{\text {grid }}-C_{w} \text {. }
$$

If $P_{\text {grid,av }} \geq 0$ and, accordingly, $\beta \leq 1, C_{\text {grid }}$ in (11) is calculated as in (9), but if $P_{\text {grid,av }}<0$ and $\beta>1, C_{\text {grid }}$ in (11) is calculated as in (10). If $C_{w, c o m}=0$, the annual investments in the wind turbine installation, including operating expenses, are equal to income from electrical energy sales to the conventional grid, so if $C_{w, c o m}>0$, the profit is stated. There are three cases, when $C_{w, c o m}<0$ :

- the income from the electrical energy sales is less than annual expenses;

- the generated energy is not on sale to the AC grid;

- there is not enough generated wind energy to provide load demand.

For further calculations it is accepted that normal operation time is 20 years and annual part of the operating expenses is $20 \%$. Therefore, $k_{\exp }=1.2$ and $k_{a}=0.06$ year $^{-1}$.

The financial efficiency factor of specific annual generation is defined as $C_{w, c o m}$ and $P_{w, r}$ relation and is equal to:

$$
\left\{\begin{array}{l}
C_{w, \text { com }}^{*}=\alpha \cdot(1-\beta) \cdot T_{a n} \cdot C_{k W h, \text { market }}-k_{a} \cdot C_{k W}, \beta \leq 1 \\
C_{w, \text { com }}^{*}=\alpha \cdot(1-\beta) \cdot T_{a n} \cdot C_{k W h, \text { grid. }}-k_{a} \cdot C_{k W}, \beta>1
\end{array} .\right.
$$

The annual equivalent cost factor depends on the load energy costs at the power grid price:

$$
C_{e q}=-P_{\text {load }, a v} \cdot T_{a n} \cdot C_{k W h, g r i d} .
$$

where $C_{k W h, g r i d}$ - the AC grid operator price for the electrical energy, EUR/kWh.

The specific annual equivalent cost factor is received by reduction of the $C_{e q}$ to the rated power of the wind turbine: 


$$
C_{e q}^{*}=-\alpha \cdot \beta \cdot T_{a n} \cdot C_{k W h, g r i d} .
$$

If all produced energy is consumed by the load $(\beta=1)$, the financial efficiency factor of specific annual generation is equal to:

$$
C_{w, c o m}^{*}(\beta=1)=-k_{a} \cdot C_{k W} .
$$

The energy produced by wind turbines is cheaper than the conventional grid energy, if $C_{w, c o m}^{*}>C_{e q}^{*}$, and this condition depends on $\alpha$ and $C_{k W}$ (Fig. 3).

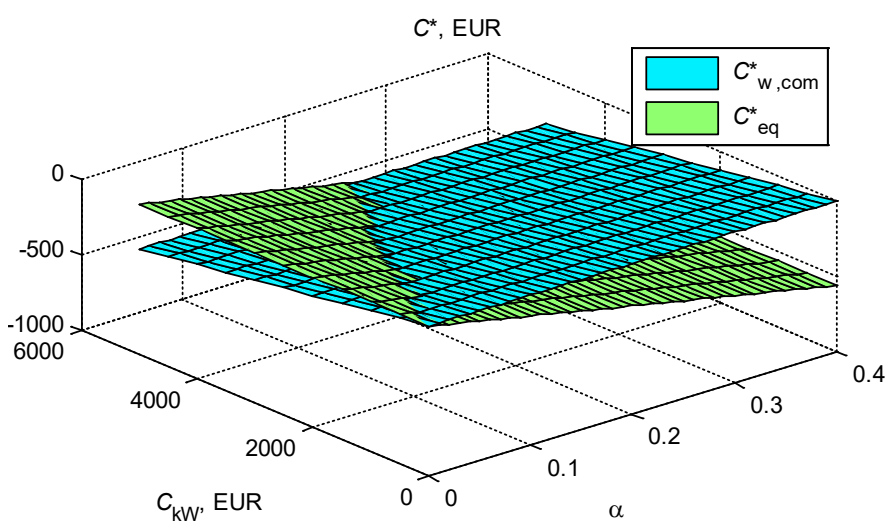

Fig. 3. The financial efficiency factor of specific annual generation comparing to the specific annual equivalent cost factor at $\beta=1$.

As shown in Fig. 3, there is a minimum necessary value of the capacity factor $\alpha_{\min }$, below which the energy produced by the wind turbine is cheaper than the energy of the conventional grid:

$$
\alpha_{\min }=\frac{k_{\mathrm{a}} \cdot C_{\mathrm{kW}}}{\beta \cdot T_{\mathrm{an}} \cdot C_{\mathrm{kWh}, \text { grid }}} .
$$

If $\beta<1$ and surplus of the produced wind energy is not transferred to the conventional grid, the minimum load $(\alpha \beta)_{\min }$, below which the use of the wind turbine is not economically viable, is defined:

$$
(\alpha \beta)_{\min }=\frac{k_{\mathrm{a}} \cdot C_{\mathrm{kW}}}{T_{\mathrm{an}} \cdot C_{\mathrm{kWh}, \text { grid }}} .
$$

and the minimum value $\beta_{\min }$ of the wind turbine power distribution factor is calculated as follows:

$$
\beta_{\text {min }}=\frac{k_{\mathrm{a}} \cdot C_{\mathrm{kW}}}{\alpha \cdot T_{\mathrm{an}} \cdot C_{\mathrm{kWh}, \text { grid }}} .
$$


If $\beta<1$ and surplus of the produced wind energy is transferred to the conventional grid, the minimum necessary value of the capacity factor $\alpha_{\min }$ is:

$$
\alpha_{\text {min }}=\frac{k_{\mathrm{a}} \cdot C_{\mathrm{kW}}}{(1-\beta) \cdot T_{\mathrm{an}} \cdot C_{\mathrm{kWh}, \text { market }}+\beta \cdot T_{\mathrm{an}} \cdot C_{\mathrm{kWh}, \text { grid. }}} .
$$

If $C_{w, c o m} \geq 0$, the profit on investments is stated, and the minimum value $\beta_{\text {max }}$ of the wind turbine power distribution factor is defined:

$$
\beta_{\max }=1-\frac{k_{\mathrm{a}} \cdot C_{\mathrm{kW}}}{\alpha \cdot T_{\mathrm{an}} \cdot C_{\mathrm{kWh}, \text { market }}} .
$$

\section{ESTIMATION OF THE PRICE OF THE PRODUCED ENERGY}

The average theoretical generated power of the wind turbine can be calculated using the power curve of the specific wind turbine and actual wind speed diagram (Fig. 4) for the specific period [19]. Calculations were made for the following turbines with similar rated power: VisionAIR5 $3.2 \mathrm{~kW}$; Windspot $3.5 \mathrm{~kW}$; Whisper 3.2 $\mathrm{kW}$; Raum Energy $3.5 \mathrm{~kW}$. Estimation of the wind turbine average theoretical power was made by creating the actual wind turbine power diagram for a chosen period and calculating its average value [19]. The example of the power diagram is shown in Fig. 5.

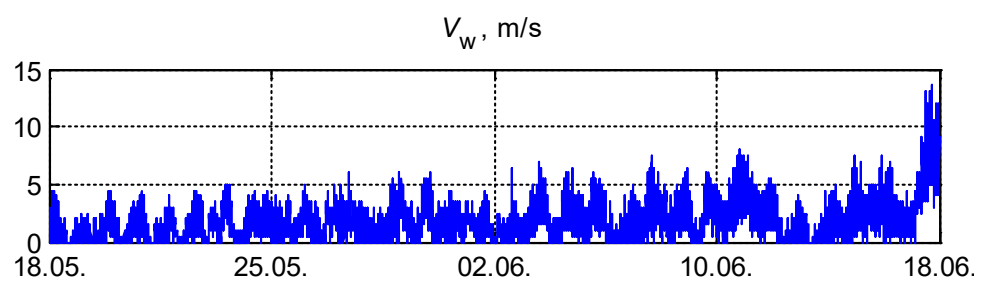

Fig. 4. Wind speed above the building of the Faculty of Power and Electrical Engineering of RTU over the time period from $18 / 05 / 2016$ to $18 / 06 / 2016$, average speed is $1.87 \mathrm{~m} / \mathrm{s}$.

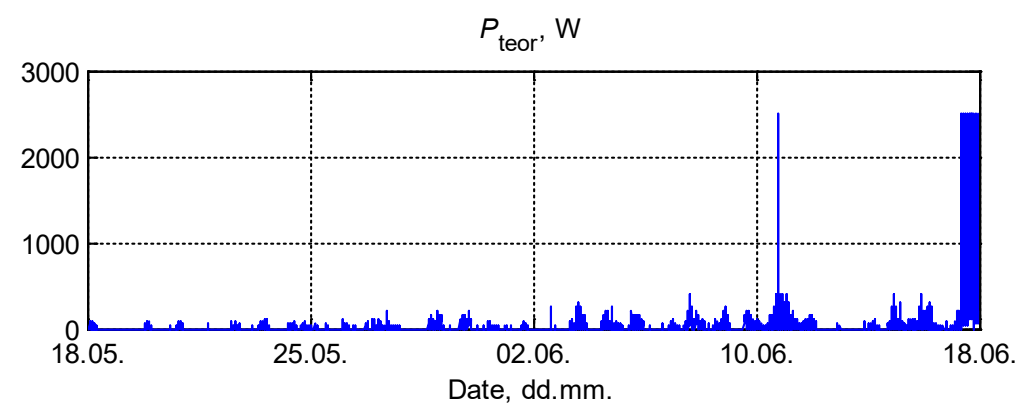

Fig. 5. The theoretical power $P_{\text {teor }}$ of the wind turbine VisionAIR5 $3.2 \mathrm{~kW}$ over the time period from $18 / 05 / 2016$ to $18 / 06 / 2016$, average power is $36.1 \mathrm{~W}$. 
The measurements of the wind speed (Fig. 4) were made above the building of RTU on Kipsala, Riga (Latvia) at the height of about 30 meters. Using the theoretical average power of the mentioned turbines, the turbine approximate prices, the actual and minimum capacity factors are calculated (Table 1). Table 1 also shows the difference between the price of energy produced by the wind turbine and the price of the conventional grid energy. It is necessary to specify that the calculation was made for a month-long period. The data about the wind speed for a longer period is necessary for more precise estimation.

Table 1

Values of Parameters of Energy Sources

\begin{tabular}{|l|c|c|c|}
\hline \multirow{2}{*}{ Energy source } & \multicolumn{3}{|c|}{ Parameters $^{1}$} \\
\cline { 2 - 4 } & $\boldsymbol{\alpha}_{\text {act }}$ & $\boldsymbol{\alpha}_{\min }$ & $\boldsymbol{C}_{\boldsymbol{k} \boldsymbol{W h}}$, EUR \\
\hline VisionAIR5 & 0.011 & 0.321 & 4.55 \\
\hline Windspot & 0.019 & 0.234 & 1.97 \\
\hline Whisper & 0.030 & 0.134 & 0.71 \\
\hline Raum Energy & 0.019 & 0.135 & 1.08 \\
\hline Conventional grid & N/A & N/A & 0.16 \\
\hline
\end{tabular}

Note: $\alpha_{a c t}-$ the actual capacity factor; $\alpha_{\text {min }}$ - the minimum necessary capacity factor; $C_{k W h}$ - the price of $1 \mathrm{~kW}$

\section{INFLUENCE OF THE NET PAYMENT SYSTEM ON THE WIND GENERATOR ECONOMIC EFFICIENCY}

The influence of the NET payment system [10] on the wind generator economic efficiency was studied in [13] and [19]. The electricity cost for $1 \mathrm{kWh}$ of each Latvian household consists of the three main components: the distribution operator service, the mandatory procurement component (MPC) and the payment for electricity. Each household must paid for operator services and MPC (60\% of the total cost for $\mathrm{kWh})$. Payment for electricity is calculated by the NET principle:

$$
E_{n e t}=E_{\text {grid,cons }}-E_{\text {grid,trans }}
$$

where $E_{n e t}$ - the amount of electrical energy for which a household must pay, kWh; $E_{\text {grid,cons }}$ - energy consumed from the conventional grid, $\mathrm{kWh}$;

$E_{\text {grid,trans }}$ - energy transferred to the conventional grid, $\mathrm{kWh}$.

Total equivalent amount of electrical energy for which a household must pay is:

$$
E_{e q}=0.6 \cdot E_{\text {grid,cons }}+0.4 \cdot E_{\text {net }}=E_{\text {grid,cons }}-0.4 \cdot E_{\text {grid,trans }} .
$$

The previous research [13], [19] has shown that the payment for electricity depends on the wind energy amount, which was directly consumed by the load without transferring to the conventional grid, and its minimum value is: 


$$
E_{\text {eq, } \min }=0.6 \cdot E_{\text {grid,cons }}=0.6 \cdot\left(E_{\text {load }}-E_{w, \text { cons }}\right) \text {, }
$$

where $E_{\text {load }}$ - energy consumed by load, kWh;

$E_{w, c o n s}-$ energy directly consumed from the wind generator.

Considering a probabilistic character of a power source and load [19], the existing rules of the power grid operator complicate the economic calculation of the wind generator. Change in the existing rules can facilitate the integration of renewable energy sources, thus having accelerated implementation of the European Parliament and Council Directives [5] and [6].

\section{CONCLUSIONS}

The methodology of evaluation of the wind turbine economic efficiency has been developed in the present research. Annual wind turbine usage costs and price of the received energy depend on the capacity factor, which is a ratio indicator of wind power utilisation per year, as well as on the ratio of energy consumed by load to the energy generated by the wind turbine. The efficiency of the wind turbine is evaluated by the use of the generation financial efficiency indicator, which indicates the return of investments (a positive value), losses (a negative value) or the investment and income equality (equal to 0 ).

The developed methodology of evaluation of the wind turbine economic efficiency can be used for determination of the wind energy price in specific places. The example of the application of the developed methodology for the specific object shows that the produced energy of the 3.2-3.5 kW turbines will be 4.4-28.4 times more expensive than the conventional grid energy. The calculation was made for a month-long period. The data about the wind speed for a longer period is necessary for more precise estimation.

The economic effect of the utilisation of the wind turbines depends on the conventional grid operator regulations and the electricity payment system, which determine a possibility for a wind turbine owner to get compensation for energy transferred to the grid. The analysis of the electricity NET payment system in Latvia has been made within the framework of the research. To describe the financial efficiency of the wind turbine, the indicator $E_{e q}$ (total equivalent amount of electrical energy for which a household must pay) has been used. The payment for electricity depends on the wind energy amount, which was directly consumed by the load without transferring to the conventional grid. The smallest value of the equivalent energy can be reached at the maximum possible energy amount generated by the wind turbine and the energy amount directly consumed by load.

\section{ACKNOWLEDGEMENTS}

The research has been supported by the Latvian National Research Programme LATENERGI. 


\section{REFERENCES}

1. Latvijas Republikas Vides aizsardzības un reǵionālās attīstības Ministrija. (2006). Atjaunojamo energoresursu izmantošanas pamatnostādnes 2006.-2013. gadam (informativa dala), Rīga.

2. Adamovičs, A., Dubrovskis, V., \& Plūme, I. (2009). Biomasas izmantošanas ilgstspējības kritēriju pielietošana un pasākumu izstrāde. Rīga: Valsts SIA Vides projekti.

3. Zaleskis, G., \& Steiks, I. (2016). Alternative energetics dc microgrid with hydrogen energy storage system. Electrical, Control and Communication Engineering, 11, 21-26.

4. Zaleskis, G., Steiks, I., Pumpurs, A., \& Krievs, O. (2015). DC-AC converter for load supply in autonomous wind-hydrogen power system. In 56th International Scientific Conference on Power and Electrical Engineering of Riga Technical University (RTUCON), 14 October 2015 (pp. 169-173). Riga: RTU Press.

5. Directive 2009/28/EC of the European Parliament and of the Council on the promotion of the use of energy from renewable sources. (2009). Official Journal of the European Union, L 140/16.

6. Directive 2010/31/EU of the European Parliament and of the Council on the energy performance of buildings. (2010). Official Journal of the European Union, L 153/13.

7. Krohn, S., Morthorst, P.-E., \& Awerbuch, S. (2009). The economics of wind energy. European Wind Energy Association.

8. Moné, C., Smith, A., Maples, B., \& Hand, M. (2015). 2013 cost of wind energy review. National Renewable Energy Laboratory: Golden CO.

9. Gadonneix, P., Nadeau, M.-J., Kim, Y. D., Birnbaum, L., Cho, H.-E., Choudhury, A.R. ... Frei, C. (2013). World energy perspective. World Energy Council.

10. Electricity NET payment system. [Online]. Available at http://sadalestikls.lv/eng/klientiem/pieslegumi/mikrogeneratoru_pieslegums/electricity_net_payment_system/

11. Microgenerator connection. [Online]. Available athttp://sadalestikls.lv/eng/klientiem/ pieslegumi/mikrogeneratoru_pieslegums/

12. Elektrum Dinamiskais and the market price. [Online]. Available at https://www.elektrum.lv/en/for-business/for-customers/ elektrum-dinamiskais-and-the-market-price/

13. Zaleskis, G., \& Rankis, I. (2016). Problem of an estimation of the wind generators economic efficiency in Latvia. In Proceedings of the 20th International Conference ELECTRONICS 2016 (pp. 16-21), Kaunas, Lithuania.

14. Bunker, K., Doig, S., Hawley, K., \& Morris, J. (2015). Renewable microgrids: Profiles from islands and remote communities across the globe. Rocky Mountain Institute and Carbon War Room.

15. De Doncker, R. W. (2012). Future DC grid technology for more decentralized power production and renewable power supplies. IEEE PEDG2012.

16. Graillot, A. (2009). Hybrid micro grids for rural electrification: Developing appropriate technology. Maputo: Trama TecnoAmbiental.

17. Karlsson, P. (2002). DC distributed power systems. Ph.D. Thesis, Lund University.

18. International Renewable Energy Agency. (2012). Renewable energy technologies: Cost analysis series, 1.

19. Zaleskis, G. (2017). Research of the automation tasks of the wind generators in the lowpower microgrids. Ph.D. Thesis (in Latvian), Riga: Riga Technical University. 


\title{
VĒJA G̦ENERATORU EKONOMISKĀS EFEKTIVITĀTES NOTEIKŠANAS METODOLOG̣IJA
}

\author{
G. Zaḷeskis
}

\section{Kopsavilkums}

Atjaunojamo enerǵijas resursu integrēšana un to tehniskās bāzes uzlabošana var ne tikai veicināt neatjaunojamu enerǵijas resursu patēriņa un ekoloǵiskās slodzes samazināšanu, bet arī nodrošināt elektroapgādi reǵionos ar apgrūtināto kurināmo piegādi vai elektroapgādes traucējumiem. Pētījumā mērķis ir izveidot metodologijiju vēja turbīnu ekonomiskās efektivitātes noteikšanai. Pētījums parādīja, ka noteiktos apstākḷos elektroenerǵija, kas tika iegūta no atjaunojamiem avotiem, var būt krietni dārgāka par iepirkto no centralizētā tīkla enerǵiju.

07.11.2017. 